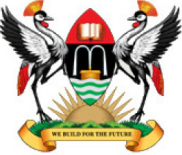

East African School of

Higher Education Studies \& Development
Makerere Journal of Higher Education

ISSN: $1816-6822 ; 3(1)(2011) \mathrm{X}-\mathrm{XX}$

DOI: http://dx.doi.org/10.4314/majohe.v3i2.2

(C) The Author(s) 2011

Reprints \& permission: EASHESD

http://ajol.info/majohe

\title{
Attitudes of Nigerian Students and Teachers towards the Teaching Profession
}

\author{
Chike-Okoli Adaeze ${ }^{1}$ \\ ${ }^{1}$ Federal University of Technology [E-mail: adaeze_okoli@yahoo.com]
}

\begin{abstract}
This study investigated the attitude of students and student-teachers towards the teaching profession in Minna, Niger State. A fifteen item questionnaire and a structured interview schedule were used to collect data from a sample of 250 respondents who were randomly selected from public and private schools within the Minna metropolis. The data collected were analyzed using frequency counts, percentages and means. The results revealed that participants held positive attitude towards the teaching profession but at different levels of significance. The implication of findings for school administration is that the attitude of students and student-teachers to teaching profession is a reflection of the attitudes of school personnel towards their career.
\end{abstract}

Keywords: Teacher training; Career guidance; School administration

\section{$1 \quad$ Introduction}

The choice of profession is very vital to parents as well as to their children. Every normal child thinks of what to do for survival and how to make a meaningful contribution to the society. What children will be when they grow up has often been a matter of intense interest to parents and manpower planners (Ipaye, 1986). In the same way, it is a well known fact that teachers are the key factors in education system and that their subject knowledge has an influence on students' learning in the classroom settings. In addition to the subject knowledge of teachers, the issues belonging to the teacher's personality and behaviour are significant contributors to the teaching and learning process for any discipline. Due to this fact, many researchers have been paying attention to determine teachers' attitudes and self-efficacy towards the subject and to find a relationship between those psychological concepts and certain variables (Abubakar, 2006; Mkpa, 1987; Moses, 2010; Danladi, 2010). 
However, recognizing that teachers' attitudes towards teaching have an effect on their classroom performance, attitudes of students and studentteachers towards teaching profession was investigated in this study.

Akomolafe (2003) pointed out that the individual's vocation or career is one of the most aspects of human endeavour because it determines a lot of things in human existence. Akomolafe further contended that true joy, happiness and satisfaction are linked to proper choice of profession. He also posited that emotional and marital stability could be enhanced by the type of occupation one engages in. In the same vein, Ikeotuonye et al (1990) stated that choice of profession is also known to influence almost every aspect of life-social class, place of living, dress, and hours of work at home indirectly, it affects an individual's attitudes and opinion, his goals and values including the way he feels about education, his outlook on life and politics. From this opinion, one can rightly say that one's profession affects so much of one's personality and life expectancy.

On a more general note, profession falls on a continuum. At one end of the continuum are high status profession privileges that are accorded to such vocations in the society. Professions in this group include law, medicine, architecture and engineering. At the other end of the continuum are low rated professions such as teaching though lowly-rated, teaching remains a unique and dynamic profession because education is a veritable tool for the building and sustenance of any nation. Musgrave (1982) stated that in many African nations it is assumed that many persons enter teaching because teaching is viewed only as a ladder through which they can climb onto other professions.

It is on this premise that the present study was conceived given the current attitude of the Nigerian society towards teaching as a profession. Generally, there is a dearth of research in the area of students and student-teachers' attitude to the teaching profession. Students are the largest and most crucial input of a school and, therefore, represent a fundamental task area of the school administrator. The services to be rendered to students should come first in the planning of a school system. This is because schools are set up for students rather than teachers, parents or educational administrators. Without students there would be no schools even if there are ample teachers and school managers (Ukeje et al, 1992; Ajayi, 2003; Abubakar, 2006).

To accomplish the goals of educational system, people with the needed skills and abilities (teachers) must be trained, employed and motivated to perform. Incidentally, job seekers desire to be employed as teachers but they do not want to identify with the teaching profession as qualified teachers. It seems that people take the teaching profession as a dump-field where a job seeker can just walk in and receive salaries until he or she can find the job he or she is looking for or get something better (Lenhart, 1999; Bello, 2007; Corneluis et al, 2007). 
This attitude has affected teaching as profession. There is need for a study in this area to provide empirical data that will guide educational administrators in raising the value of the teaching profession and thereby attract the right kind and quality of teachers to our schools. Taking the case of Niger State (Nigeria), therefore, this study undertook to assess the attitudes of student-teachers and secondary school students towards the teaching profession and the implications of these attitudes for school administration. Specifically, the study was motivated by a desire to understand why school leavers prefer to teach without training as teachers? And why they accept to teach but look down on teaching as profession? These questions point to the perception of school leavers as far as teaching as a profession is concerned. Therefore, the study delved into the perceptions and beliefs that students hold about the teaching profession and the attitudes of student-teachers towards the teaching profession. It undertook to respond to three research questions: 1) what are the attitudes of secondary school students towards the teaching profession? 2) What are the attitudes of student-teachers towards the teaching profession? 3) What are the implications of students' attitude towards the teaching profession?

\section{$2 \quad$ Methodology}

\subsection{Design}

The design of this study was Descriptive Survey. It was a survey research with the aim to collect data from one group to describe some characteristics of the group (Burbules and Densmore, 1991).

\subsection{Population and Sample}

The study targeted all students and teachers in secondary schools and studentteachers in the College of Education, Minna, Niger State. The research involved a total of one hundred and fifty (150) secondary school students and one hundred (100) student-teachers randomly drawn from five (5) secondary schools in Minna zone of Niger State. The five (5) secondary schools were chosen based on age of school, experience and qualification of staff, population and comprehensive nature of the schools. It is believed that the chosen schools are representative of secondary schools in Niger State. Stratified random sampling was applied in the choice of schools. 


\subsection{Instrumentation}

The major instrument used for this study was a researcher designed 15 items "Teaching Attitude Scale" (TAS). A five point Likert type response (Strongly Agree (SA), Strongly Disagree (SD), Undecided (U), Agree (A), and Disagree (D) was used. The questionnaire was pilot-tested to test the question items. The scores awarded were correlated using Spearman Rank Order coefficient of correlation. The Split-half reliability coefficient was found to be $0.84,0.89$, 0.90 and 0.94 respectively for the sub-scales tested. Structured interview schedule (consisting same fifteen (15) items) was developed also to elicit more responses on attitude towards the teaching profession.

\subsection{Data Analysis}

The scores obtained from the use of the instruments were analyzed using frequency, simple percentages and mean scores. For the performance level test, respondents indicated their views by choosing one of the following: 'Strongly Agree', 'Agree', 'Undecided', 'Strongly Disagree' and 'Disagree'.

The frequencies were grouped into two parts, indicating either agreement or disagreement. Any response under 'Strongly Agree' was accepted as agreeing with a stated point of view, but 'Strongly Disagree' and 'Disagree' indicating disagreement over the issue raised in the questionnaire. 'Undecided' was neutral. The respondents' frequencies were converted to percentages.

A higher percentage would indicate positive performance. However, to arrive at a decision level, the mean of the total percentages under each item on a scale was found. $50 \%$ was arbitrary chosen as the average or neutral point. The researcher considers $50 \%$ as adequate, because, it is half of $100 \%$ which is the ideal standard.

Any mean percentage above $50 \%$ would indicate positive attitude while those below $50 \%$ would indicate negative attitude. The concept of percentages is useful, because, it enables the layman to see at glance the relationship between scores.

\section{$3 \quad$ Findings and Discussion}

The findings were that majority (95\%) of the respondents "Agreed" that the teaching profession is a 'ladder' to other professions and that teachers are not sufficiently remunerated $(81 \%)$. However, majority of the respondents were more positive about the other attributes of the teaching profession investigated (Table 1). 
Table 1: Attitudes towards Teaching Profession

\begin{tabular}{llllll}
\hline & \multicolumn{3}{c}{ Agree } & Disagree & \multicolumn{2}{c}{ Total } \\
& Count \% & Count \% & Count $\%$ \\
\hline Teaching profession is a ladder to other professions & 232 & 9512 & 5 & 244 & 100 \\
Students enter teaching as a resort & 107 & 43140 & 57247 & 100 \\
Student seem to feel ashamed to be teachers & 70 & 29169 & 71239 & 100 \\
Teaching profession is not sufficiently remunerated & 202 & 8147 & 19249 & 100 \\
Teaching profession is not sufficiently attractive to & 90 & 37154 & 63244 & 100 \\
students & & & & & \\
Teaching profession is more accessible than other & 98 & 41140 & 59238 & 100 \\
occupations & 158 & 6586 & 35244 & 100 \\
Too much of teacher's work has to be in-door & 180 & 7560 & 25240 & 100 \\
Teaching is a noble profession & 230 & 9220 & 8 & 250 & 100 \\
I would like to read course(s) related to teaching & 120 & 52110 & 48230 & 100 \\
Teachers are good trainers of other professionals & 219 & 8830 & 12249 & 100 \\
I like teachers because they are masters of knowledge & 169 & 6880 & 32249 & 100 \\
I like teaching because it gives one more time to relax & 1692 & 8536 & 15238 & 100 \\
I like teaching because teachers produce good citizens & 202 & 254 & 7490 & 26344 & 100 \\
\hline Teaching helps one think logically & 254 & & &
\end{tabular}

Table 1 shows that 250 respondents indicated their responses as strongly agreed, agreed, undecided, strongly disagree and disagree. For instance, analysis on table 1 shows that 120 of the respondents (48\%) strongly agreed and $112(44.8 \%)$ simply agreed with the statement that teaching profession is a ladder to climb into other professions while 12 respondents (4.8\%) simply disagreed and none strongly disagreed. The mean response (point value) of 92.8\% indicated agreement with the statement.

Furthermore, responses of the students to the second item on the table revealed that $90(36 \%)$ simply disagreed that students enter teaching as a resort while $50(20 \%)$ strongly disagreed. On the other hand, 38 (15.2\%) strongly agreed while $69(27.6 \%)$ simply agreed with the statement. The higher mean response of the respondents to item 2 was 140 (56\%) which shows acceptance.

Data presented in respect of item 1-15 indicated that the majority were in agreement with the favourable statement concerning the teaching profession. In other words, most of the students and student-teachers exhibited positive attitude towards teaching profession.

The findings show that senior secondary school students and student teachers sampled exhibited a positive attitude towards the teaching profession. This finding tends to draw support from other studies (Ehiametalor, 1985, Musaazi, 1982) which concluded that most individuals recognize the rights of teachers and their roles in educational development. However, other studies such as (Nwaogu, 1999; Ezeanolue, 1990; Musgrave, 2002 and Bello, 2007) found out 
that most African societies exhibit a negative attitude towards the teaching profession. The possible rational for students to have positive attitudes towards the teaching profession may be due to the recent professionalization of teaching in Nigeria. The establishment of Teaching Registration Council (TRC) (a regulatory body that ensures that teachers behave well as professionals who uphold the ethics of their profession) could have contributed a lot towards improving the image of the teaching profession and subsequently the attitude towards teaching. Registration with TRC makes it mandatory that teachers acquire specialized knowledge and intensive academic preparation which allows the teacher to display business-like qualities that characterize members of a credible profession (Goodlad, 1990; Chike-Okoli, 2007; Yerima, 2010).

Given the improved standard of living in the ambient environment, it is likely that the self-esteem and self-concept of individual teachers might be such that endears personal confidence and fulfilment in the teachers. The positive attitude of the teachers might be the influencing factor that occasioned the shift in the attitude of students towards teaching. The teachers scored a mean of 38.6 out of 50 on the question concerning their attitude towards the teaching profession. This is a high means score, indicating that they regarded the profession highly. Therefore, the study implies that:

1. Teaching was perceived to be a noble profession that is meaningful, worthwhile and satisfying. Findings indicate that the students sampled were clear that good citizens are produced by teachers, teachers are good trainers of other professionals and that, teaching helps one think logically.

2. Teaching was perceived as interesting, enjoyable, exciting and challenging because it has to do with communicating with and relating to people. The nature of teaching in itself that produces good citizens and other professional was a good enough reason for some of them to want to teach.

3. Teachers needed to have certain qualities, attitudes and depositions before they could become 'good' teachers. These included commitment, enthusiasm, interest and professionalism besides many others. As these were unsolicited comments, they showed that many of the participants realized the importance of teachers having the right values and attitudes. The implication therefore is that teachers would also need to be equipped with many different skills and much pedagogical knowledge in order to teach successfully and effectively, and to meet instructional challenges posed by the many educational changes and new initiatives.

\section{$4 \quad$ Conclusion and Recommendations}

This is a report on the perception and beliefs of teaching held by a representative, but randomly selected group of fifty 'beginning' student 
teachers. It was shown that they had generally positive perceptions of teaching and held certain expectations of teaching as a job. The findings gave insights to how the participants viewed their career choice, and provided some useful baseline data for the developing of an enhanced initial teacher preparation programme that could address some of the major issues surfaced in this study.

Therefore, efforts should be made to encourage students to choose a career in teaching. They should be made to understand that careers in teaching are attractive, prestigious and noble. Parents, guardians and other concerned individuals have a lot to do in this regards. Workshops and seminars need to be organized on the essence of teaching profession in overall educational development in the country.

Teachers need to conduct themselves in manner befitting their professional ethics and maintain highest standard so as to portray a good image of the profession both to the students and the entire society.

As it was mentioned before, teachers are one of the most important factors in the teaching and learning process. Their attitudes towards the subject, school, and teaching have an influence on student's learning and attitudes towards discipline, school and career choice. That's why conducting such studies to determine the teachers' personality traits or perceptions about teaching and learning are highly recommended for future researchers.

\section{References}

Abubakar, A. A. (2006). Teacher as central factor for effective management \& Quality control of Universal Basic Education (UBE) in Katsina State. Journal of Educational Management and Planning. Vol. 1 (1) 92-100.

Ajayi, F. O. (2003). The Problems and prospects of Teacher Education in Nigeria. Knowledge Review. Vol. 6 (3) 110-114.

Akomolafe (2003). Relationship Between Fathers Occupational Status and their Children's Occupational Preference. Journal of Research in Counselling Psychology 9, 127-131.

Bello, Ahmed (2007) Repositioning the Teaching and Learning of Integrated Science in Nigeria to Reflect its meanings, objectives and Philosophy. NASHER Journal. Vol. 5 (1) 66-71.

Chike-Okoli, (2007) Issues in School Administration. Minna: ASODOC Publishing House.

Cornelius M. F., Bulus, S., Gbari, U. S. (2007) Functional Education as a Spring Board for National Development. NASHER Journal. Vol. 5 (1) 147150. 
Danladi, Yerima (2010) "Attitudes of Students and Teachers towards Teaching Profession". An unpublished M.Ed Thesis. Lagos: National Open University of Nigeria.

Ehiametalor, E. T. (1985). Strategies in Management of Education. Ibadan, Evans Brothers (Nig. Publications) Ltd.

Ezeanolue, A. (1990). "An Evaluation of Supervisory Activities of Supervisory Personnel in Post Primary Institutions in Jos zone of Plateau State. An unpublished M.ED Thesis, University of Nigeria.

Federal Republic of Nigeria (2004).National Policy of Education (Revised). Lagos: Federal Government Press.

Goodlad, J. L. (1990). Teachers for our nation's schools. San Francisco. Jossey-Bass.

Ikeotuonye, A, Olufeagba, B., Gambari F (1990). Career Guidance: A Vocational Approach for Schools. Zariah: Hudaltuda Publication.

Ipaye, T (1986). Educational and Vocational Guidance: Concepts and Approaches. Ife: University press.

Lenhart, V. (1999) Basic education: theoretical objectives and practical measures. Education, Vol.1. (1) 8-13.

Mkpa, W. A. (1987). Teacher preparation for a successful UBE in Nigeria, A lecture delivered at ANCOPS Conference.

Moses K. K. (2010). "Challenges of implementation of Universal Basic Education UBE in Niger State". Unpublished M.Ed Thesis, Lagos: National Open University of Nigeria.

Musaazi, J. C. S. (1982). The Theory and Practice of Educational Administration. Lagos: Macmillan.

Musgrave, P (2002). Sociology of Education. New York: Heinemann Books Ltd.

Nwaogu, J. I. (1999). A guide to Effective Supervision of Instruction in Nigerian schools, Enugu: fourth Dimension Publishers.

Ukeje, B. O., Akabogu, G. C., Ndu, A. (1992). Educational Administration. Enugu: Fourth Dimension Publishers.

UBE (2006). The State of the UBE Programme. UBE Manual. Abuja: Federal Ministry of Education Publication. 